\author{
CELESTINO DELEYTO \\ University of Zaragoza
}

GEMMA LÓPEZ

University of Barcelona

\title{
Catalan beauty and the transnational beast: Barcelona on the screen
}

\section{ABSTRACT}

\begin{abstract}
This article explores the case of Barcelona as paradigmatic global city in such transnational productions as Vicky Cristina Barcelona by Woody Allen (2008) and Biutiful by Alejandro González Iñárritu (2010). Allen's film shows the extreme dilution that national and linguistic identity undergoes under foreign eyes in its rendition of a 'hip Barcelona' for tourists 'invaded' by transnational subjects in search of bourgeois pleasures. Maybe in pursuit of a more 'real' city, Iñarritu's Biutiful moves to the Barcelona of the immigrants and the undocumented, a transnational and paradoxical location inhabited by those who need to cross borders in order to survive. Through reference to the work of Manuel Castells, Saskia Sassen, Neil Smith and Michel De Certeau among others, we argue that neither of these representations of the city is more real or unreal than the other. In their drastically divergent ways, both films contribute their divergent external perspectives to the imaginary construction of Barcelona as a fascinating global city and can be seen as a dyptich of a transnational Barcelona. Further, they contribute to the ongoing debate about the polarization between the local and the global, the construction of urban frontiers inside the cities through gentrification, the alterations of the places we (would like to) inhabit, and the translation of all these into visual terms.
\end{abstract}

\section{KEYWORDS}

Barcelona

Woody Allen

Alejandro González

Iñárritu

globalization gentrification film studies 
In 2009 the then mayor of Barcelona, Jordi Hereu, invited some residents of the district of Ciutat Vella (Old Town) to an interview at the Town Hall with a view to discussing the problems of the area. Most of the questions and frustrations addressed to the authorities had to do with the conflict between the process of gentrification that Ciutat Vella is undergoing and its resilient character as a 'dodgy' area of town. The debate focused on one of the district's neighbourhoods: el Raval. The district, once home of the Catalonian labour movement and Bohemian hub, had fallen into a lethargic state at the start of the 1980s, witnessing the rise of drug trafficking and prostitution. Raval was a collection of sordid streets where a marginal segment of the population tried to survive. Barcelona citizens knew what to expect when they ventured into its labyrinthine streets: a maze of both male and female prostitution, sordid clubs and music halls, poverty, gloomy corners, and a stimulating atmosphere of risk and danger. From the 1990s on, however, the whole area has undergone a systematic process of rehabilitation brought about by Barcelona's local authorities and urban planners.

At the meeting with the mayor, one of the most controversial issues was the problem of shopping for groceries: both nearby markets have become popular tourist enclaves which sell products designed exclusively for tourists. Discouraged residents find that services which were once destined to them have been subtly 'colonized' by (globalized) passengers in transit. Also top-quality cultural facilities have gradually invaded this old neighbourhood and extended to other parts of the Ciutat Vella: the Museum of Contemporary Art and the Centre de Cultura Contemporània, several university buildings, the reconversion of the marina into a leisure centre, and the recovery of public spaces. Most controversially, a wide promenade, the 'Rambla del Raval', was opened in 2000 in the midst of narrow, winding streets, becoming paradigmatic of rehabilitation projects worldwide. As part of this plan around the new Rambla, a project was initiated but not yet completed that would include a luxury hotel, a shopping mall, a car park, a block of flats and the new headquarters of the Catalan Film Theatre. Most of the 450 families who lived in the area were offered meagre economic compensations and forced to leave the city or move to more precarious homes, given that property prices in the area had soared well beyond their means in their old neighbourhood (Delgado 2010: 59-60).

This was the most famous intervention carried out by the local authorities in their sustained effort to reform the coveted space. With the exception of this new boulevard, however, the structural layout of the district - a maze of narrow and chaotic streets where non-residents tend to lose their way - has not altered much. Social heterogeneity continues to be a peculiar feature of an area that has witnessed the massive arrival of non-European immigrants, thus contributing to the image of multicultural Barcelona which local authorities so proudly advertise. Today, at the Rambla del Raval, the casual visitor may see an old building beautifully decorated by squatters opposite the luxury hotel; Pakistani children playing baseball in front of the same hotel's main entrance while groups of undocumented African citizens hover around; a homeless woman sleeping under the enormous Pedro Botero Cat sculpture in the middle of the promenade; curious passers-by stopping in front of construction sites, mixed with the local prostitutes displaying their wares and sizing up potential customers; all surrounded by banners hanging from numerous flats demanding dignity for the neighbourhood.

The transformation of Raval is not an isolated phenomenon, but rather part of a larger process that was propelled by the two most important cultural 
events witnessed by the city in recent times: the Olympic Games of 1992 and the Fòrum de les Cultures of 2004. The fairy tale of the grey, ugly Barcelona turned as if by magic into the belle of the ball followed a pattern familiar in other global cities. As Catalan architect Josep Maria Montaner anticipated as early as 1986, the new Barcelona of the Olympic Games and beyond would be exported universally as a desirable tourist destination, a fierce business centre, a city based on modern design and architecture, a trademark of itself which would be based on consumerism and speculation (1986: 31-32); 25 years later this premonition has turned into a process known as 'Barcelona Marca Registrada', the city as trade mark. More recently, Manuel Delgado has complained that the city has become a model, an example for urban planners and architects around the world to imitate, a paradigm of growth and harmony; but also a model in the sense of top model - a person who has been trained to remain permanently attractive and alluring (2010: 13). ${ }^{1}$

Recent cinema has been an attentive witness of this process. Representations of the Catalan beauty in the throes of momentous changes continue to grow and offer complex perspectives of the city. In this article, we would like to focus on two 'external' views of this new, global Barcelona: Woody Allen's Vicky Cristina Barcelona (VCB) (2008) and Alejandro González Iñárritu's Biutiful (2010). Both films have been attacked for failing to produce a 'real' Barcelona precisely because their creators are not local, but both share a fascination with contemporary urban dynamics. Taken together, they constitute a privileged diptych of the successful projection of the Barcelona trademark as a global, transnational city and provide a joint map of an imagined yet familiar city. They make spectators aware of the generally invisible, but sometimes very visible, borders that such phenomena as globalization, gentrification, immigration and tourism create inside cities. In terms of production, Allen's film is essentially a Spanish film, with some participation from the Weinstein Company. Biutiful is a Mexican Spanish co-production, with the participation of Focus Features. Both films share a pattern of diversified international deals for distribution and, more interestingly, generous funding from Spanish and Catalan institutions, including nationwide and Catalan TV channels and political bodies. ${ }^{2}$ In both cases, the production and distribution patterns revealed an interest from local institutions in selling a certain globalized view of the city and ensuring the worldwide visibility of their product.

At first sight, the characters of $V C B$ and Biutiful are clearly divided along class lines: in Allen's film we see almost nothing but middle-class tourists and (some) local citizens; Biutiful is almost exclusively populated by immigrants, both from the waves of internal immigration that headed for Barcelona from the South of Spain in earlier decades and the more recent international immigrants. Both movies are recognizably about Barcelona, yet looking at the two in succession it is hard to believe that they are set in the same city. With some exceptions, the plot of $V C B$ takes place in the gentrified Ciutat Vella and, occasionally, other privileged enclaves, whereas the characters of Biutiful, while extremely mobile, inhabit the thickly populated working-class suburbs North of the city (Badalona and Santa Coloma de Gramenet), areas which the cinema has never paid much attention to. One is tempted to say that Barcelona's gentrification has pushed immigrants away from Ciutat Vella to make room for intellectuals, artists, tourists, and wealthy visitors of the type we find in $V C B$. If a film-maker wants to explore the predicament of immigrants in the global city, as is the case of Iñarritu in Biutiful, he or she must move to the margins. Yet, the demographic structure of a global city like Barcelona is not as simple as this division suggests. Raval illustrates precisely this.

\footnotetext{
1. For a more ironic take on the 'Barcelona model' and the 'Barcelona trademark' notions, see Caellas (2011), whose title turns the name of the city into a word meaning 'big jail'.

2. Sources: Imdb, Firtshowing.net, Variety and Biutiful's production notes.
} 
While the borders between the fictional worlds of Allen's and Iñarritu's films appear to be separated by insurmountable barriers, they are actually much closer than they seem. Biutiful is particularly aware of the extreme complexity of the social structure of the global city and of the porosity of its internal borderlands. Like the citizens of the panorama city described by Michel De Certeau, who, with their 'microbe-like, singular and plural practices', contradict, ignore or transgress the limits imposed by the urban network (1984: 96), the characters in this film make the city their own through their daily exchanges. Both films, on the other hand, push into their margins, but cannot make completely disappear, debates about local and national identity, and their relationship with globalizing processes, specifically, what Manuel Castells described, using the example of Catalonia, as the identity of nations without states (2004: 51-52).

\section{THE MANY SIDES OF GENTRIFICATION AND THE USES OF LANGUAGE IN VCB}

$V C B$ is typically Allen, a film about the urban intellectual middle classes for an urban intellectual middle-class audience. The film narrates the sentimental adventures of two young US women during one summer in Barcelona. In the course of a few weeks, Vicky (Scarlett Johansson) and Cristina (Rebecca Hall) fall in and out of love with local painter Juan Antonio (Javier Bardem) and, in one case, also with his ex-wife María Elena (Penélope Cruz). When the summer is over, they both return to the US, Cristina to married life with dependable but boring Doug (Chris Messina) and Vicky, alone again and still searching. The presence of the two Spanish characters among its quartet of protagonists is relatively unusual in a corpus of narratives in which, no matter where the action takes place, most of the characters are, one way or another, New Yorkers. Yet the predominant perspective both on the action and on the city is a US-centred perspective. This is the Barcelona that an American tourist may experience, but also the Barcelona constructed by the authorities for (American) tourists. In the film, editing ensures that pretty locations are linked spatially to one another as if there was nothing in between: Juan Antonio (Bardem) lives in a house located in a wealthy area on the slopes of Vallvidrera, and so do the distant relatives with whom Vicky (Rebecca Hall) and Cristina (Scarlett Johansson) are staying. Yet, most of the rest of the action takes place in recognizable spots of the relatively distant Ciutat Vella, as if there was nothing in between. Arch-famous Catalan architect Antoni Gaudi's most emblematic sites, the Sagrada Familia, the Parc Güell, and la Pedrera, figure prominently in the film, as do some museums, several Miró artworks, the Casa Fuster hotel, the Ramblas and various locations in the narrow streets of Raval (Figures 1-2).

As a whole, Allen's Barcelona is a clean combination of architectural landmarks, sunny street markets, designer shops and restaurants and trendy contemporary art forms, a Barcelona which comes close to the trademark imagined and promoted by local and regional authorities and built by global capital. Spanish critics fell down heavily on the film, attacking its manipulative, picture-postcard version of the city and the warped perspective of unimaginative tourists (see Casas 2011; Sánchez 2011). However, Allen's Barcelona is as familiar to us from tourist guides, advertisements and promotional campaigns as the Barcelona experienced by locals. Allen's Barcelona constitutes a specific use of the capital's process of gentrification, one which is part of the expansion of this process in recent decades all around the world.

1. 2. 3. 4. 5. 6. 7. 8. 9. 10. 11. 12. 


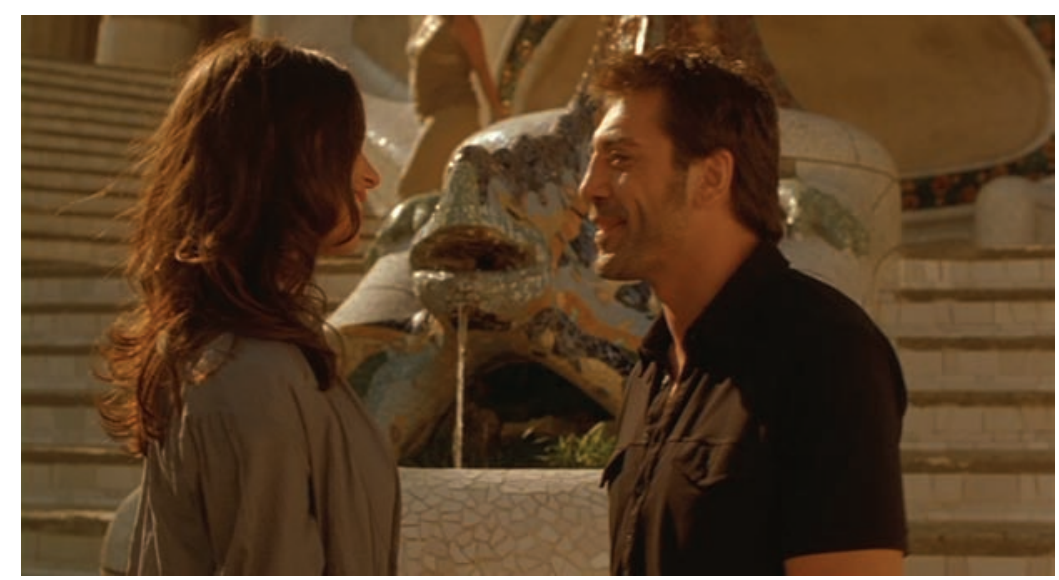

Figure 1: Transnational love in Gaudís Barcelona.

But what exactly is gentrification? For Jeremy Seabrook, cities seem to be literally dissolving into bourgeois sites rebuilt entirely for the beneficiaries of globalization who recolonize en masse their urban historic centres (2008: 26). This is part of a non-official, pseudo-spontaneous movement of 'going back to town' on the part of middle and upper-class professionals (Seabrook 2008: 55). Neil Smith explains that the term 'gentrification' was coined in the 1960s by sociologist Ruth Glass to refer to the process whereby many working-class districts were being turned into elegant, expensive residences for the middle classes, displacing their original inhabitants and changing their social character. These 'renovations' became incorporated into urban policy as local authorities turned them into increasingly essential features of their developmental strategies. In the 1990s these strategies became global when private capital turned them into crucial areas of investment. Smith offered a vivid picture of this process:

[D]owntowns are being converted into bourgeois playgrounds replete with quaint markets, restored townhouses, boutique rows, yachting

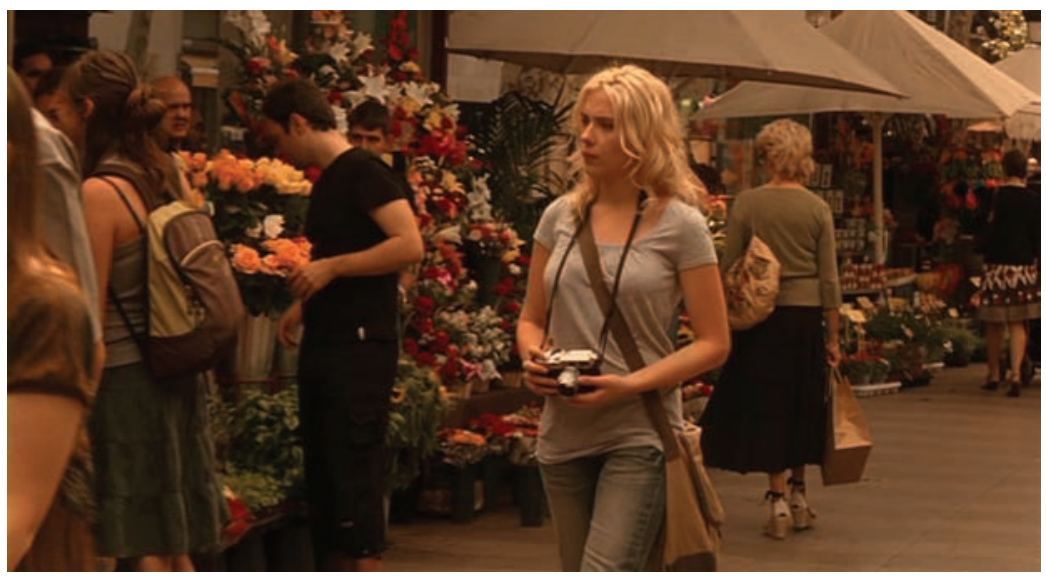

Figure 2: The scent of Catalan beauty. 
marinas, and Hyatt Regencies. These very visual alterations to the urban disequilibrium but are as rooted in the structure of capitalist society as was the advent of suburbanization.

(1982: 152)

In spite of frequent resistance, gentrification appears to be unstoppable. It has started to spread from the city centres and it is becoming a centrepiece of the city's productive economy and an end in itself. Also, what started in Europe, North America and Japan has now extended to Asia and Latin America (Smith 2002: 438-43). Gentrification intensifies tensions between neighbourhoods in big cities. As successive waves of immigrants continue to flock into these urban spaces, larger areas become gentrified, invisible and sometimes visible walls being erected in front of those without the economic means to afford them. Working-class neighbourhoods, once full of energy and vitality, are 'rehabilitated by middle class homebuyers, landlords and professional developers' (Smith 1982: 139), causing property values to increase and having the side effect of driving poorer families away (Schaffer and Smith 1986: 347). Lower-income families as well as newcomers are pushed towards fastgrowing slums, which might themselves become renovated.

The space within which the characters of $V C B$ move reflects the result of this process of gentrification. Allen's Barcelona, much like his New York of previous movies, is a city that has been cleared of the poor and unsightly for the pleasure of its wealthy inhabitants. Yet some relatively local people remain in the story, and these end up provoking the narrative conflict of the story. We have argued that the film tends to elide the transitions between distant beautiful locations, reducing the size of Barcelona to that of a little town. Yet the idea of movement remains a crucial feature of Allen's version of the gentrified city. The protagonists arrive and leave by plane, Juan Antonio travels twice to Oviedo covering over 900 kilometres without any apparent effort. In general, the protagonists walk restlessly and perform a kind of dance that includes arranged meetings in cafes, restaurants, art galleries and fortuitous encounters in street corners, parks or museums. Allen's characters continue to wander around the city in their search for a state of sexual contentment that forever eludes them.

There is nothing unusual in this metaphorical choreography for connoisseurs of Allen's oeuvre, except that, in VCB Juan Antonio and María Elena manage to upset the balance and introduce an unexpected ingredient in the familiar recipe, one that goes beyond the conventional exoticism associated with foreigners in US movies. Bardem's Juan Antonio starts primarily as the object of desire of the two American friends, but as the plot develops, first Juan Antonio and then María Elena acquire increasing narrative prominence. María Elena's sudden appearance gives more depth to the two Spanish characters and liberates them from the clichés on which their construction was initially based. This narrative development turns them into more formidable 'others' to the US women, and complicates and thickens the experience of desire circulating among the four principals.

Two main love stories, as well as a couple of subsidiary ones, emerge with the common denominator of Juan Antonio at their centre: the love triangle turned ménage à trois between Cristina, Juan Antonio and María Elena; and the more conventional triangle between Vicky, her fiancé-then-husband Doug and Juan Antonio. In both of them, the partners' cultural identities prove crucial.

2.

3.

4.

5.

6.

7.

8.

9.

10.

11.

12.

13.

14.

15.

16.

17.

18.

19.

20.

21.

22.

23.

24.

25.

26.

27.

28.

29.

30.

31.

32.

33.

34.

35.

36.

37.

38.

39.

40.

41.

42.

43.

44.

45.

46.

47.

48.

49.

50.

51.

52. 
1. Cristina and Juan Antonio's love affair starts more or less conventionally as a

2. holiday romance between a man and a woman from two different countries, 3. but things change drastically with the unexpected interruption of María Elena. 4. Interestingly, the dynamics of this triangle is constructed from the beginning 5. around a linguistic mismatch. Juan Antonio has spoken English to both Vicky 6. and Cristina from the beginning, and only his first visit to his father, who 7. refuses to speak any language but Spanish, has the son mediating between the 8. older man and Vicky, whose Spanish is surprisingly poor for somebody taking 9. a Master's in Catalan identity. But when María Elena unexpectedly appears 10. in the house, things begin to change. Cruz initially rehearses the role of the 11. hot-tempered and sexually dangerous Hispanic that English-speaking audi12. ences had become familiar with from her previous Hollywood films (see Shaw 13. 2007: 34-38). Gradually, however, she departs from this well-known image 14. and comes to add interesting new meanings to the formula. She keeps refus15. ing to speak English, even though she is perfectly capable of it, and seems to 16. use both languages as her way to become part of the relationship. Language 17. alternation constitutes the central representation of borders and borderlands 18. in $V C B$, apparently as a barrier to communication but increasingly propel19. ling the free flow of desire and representing the hybridity of national identity. 20. María Elena's otherness is partly conveyed through her use of Spanish but also through her peculiar appropriation of English. Her mixture of the two languages and her idiosyncratic way of using the other's tongue is an index of what both inhibits and fascinates Cristina about her. With her around, Juan Antonio also speaks more Spanish than before, revealing a different side of his. He is no longer the local speaking to tourists in their tongue, becoming a more complex character. By keeping the coexistence of the two languages in this relationship beyond what is customary in most films, Allen calls our attention to the centrality of linguistic diversity in encounters between different cultures. The new dynamics established between the characters change Cristina's experience of Barcelona: she has managed to establish herself in the borderland between the two cultures; she is a new person more aware of the potential and the uniqueness of intercultural and transnational exchanges.

Vicky's experience of the cultural border is different. She feels trapped into a commitment and then marriage of which, deep down, she is mortally afraid, because it will bring about the end of her youth and sexual independence. Her attraction to Juan Antonio's otherness is a symptom of her dissatisfaction. She is reluctant to break with social conventions but has sex with Juan Antonio. Both characters are more affected by the experience than they had anticipated and, in a sense, spend the rest of the film attempting to revive that experience, a reunion finally frustrated by María Elena's second return. Vicky is initially dismissive of Juan Antonio's all-too-obvious sexual advances and of his pose as the sexually liberated European man looking for adventures with gullible American tourists. Yet, in her aggressive and somewhat comical response to his sexual proposition the spectator may detect a criticism of his appropriation and trivialization of cultural difference as the engine of desire. As the plot unfolds, she gets married to Doug but silently holds onto her desire for Juan Antonio, secretly hoping to replace her trustworthy husband with the unreliable foreigner, to re-imagine herself as the desiring subject of the borderlands. More than Cristina and even Juan Antonio, she turns out to be the one who sees herself most at home in a potential scenario of cultural hybridity and becomes a gifted, if ultimately frustrated, inhabitant of the urban border. 52. Conversely, her facial expression at the end of the movie and the outset of 
her new conventional life with reliable and wealthy Doug in Manhattan is as poignant and distressing as that of the protagonists of more 'tragic' Allen films like Crimes and Misdemeanors (1989), Match Point (2005), and You Will Meet a Tall Dark Stranger (2010). For her, giving up the borderland and the fascination of the other is like being buried alive.

Many contemporary global cities are modern-day Babels in which communication takes place in a multiplicity of languages. Bringing together the Biblical myth and the global city, Nataša Durovičová describes the latter through a variety of tropes: 'a new world order, an urban project, pathways of extreme - even sublime - complexity, a nexus of communication technologies informing the built environment, the Promethean dimension of utopian projects'. However, she also notes the flip side of the myth's coin: 'It might well be that we now are able to communicate with as many people as possible, but the story of "Babel" is another way of also asking, "Do we want to?"' (Durovičová 2003: 73, 72). Allen's film, faithful to the spirit of comedy, optimizes the utopian potential of linguistic variety and of the modern city. Cristina's fascination with María Elena and her excitement at the possibilities of the threesome is, as we have seen, partly related to the way the Spaniards communicate with one another in front of her. This fascination can be said to represent a more general textual fascination with the encounter between English and Spanish. For Allen Barcelona represents a form of liberation, a paradise of bilingualism. Yet, in exposing his English-speaking protagonists to the language of the other, the movie may be said to contradictorily threaten and dilute the identity of the city as registered mark that it otherwise appears to promote. With its English-speaking narrator and its cast of mostly American characters speaking nothing but English, VCB follows its textual desire by allowing more and more Spanish being spoken in its midst. Yet, something continues to be missing that is an essential ingredient of that registered mark: the Catalan language.

In the spirit of helping bring Barcelona to international visibility, Allen affirms in the film's official page that his goal was to turn the city into another character, to honour a city that for him is very romantic and full of visual beauty (Allen 2008: official film web page). As a result, the film-maker gives us the image of a hip Barcelona for tourists, full of cultural excitement and permanently crossed by transnational subjects in search of bourgeois pleasures. For those to whom this film is addressed, the identity of the city must be understandable within certain recognized parameters, while at the same time holding the promise of something different, something that can make their experience 'unique' and their relationship with the city 'special'. In the same web page, Rebecca Hall points in this direction when she says,

Barcelona has all the elements of a great European city in terms of beautiful architecture, but there's also something underneath the surface that is quite anarchic. [...] It's got a really strong spirit as a city and the people there are very proud of it - they like to define themselves as outside of Spain. It stands on its own with its unique culture and identity (Hall 2009: official film web page). Here Hall is speaking almost in character, introducing us to the background of Vicky's academic interest in the city and her knowledge derived from her M.A. in Catalan Studies. Hall's description, however, says very little about the cultural specificities of Catalan identity, nothing about the ideological debate surrounding national identity, and, in typically collapsing Barcelona and Catalonia, erases the city's individuality even as it is trying to assert it.

2.

3.

4.

5.

6.

7.

8.

9.

10.

11.

12.

13.

14.

15.

16.

17.

18.

19.

20.

21.

22.

23.

24.

25.

26.

27.

28.

29.

30.

31.

32.

33.

34.

35.

36.

37.

38.

39.

40.

41.

42.

43.

44.

45.

46.

47.

48.

49.

50.

51.

52. 
1.
Barcelona is a bilingual society. Catalan and Castilian Spanish coexist to various degrees and both have the status of official languages. More importantly, Catalan is the principal marker of Catalan national identity and its greatest differentiating factor (Marfany 1995). While the majority of people in Catalonia are bilingual, they have a primary mother tongue, which may be Catalan or Spanish. Linguistic issues, such as the politically fraught debate around so-called 'linguistic normalization' are central to understanding contemporary Catalan society and are inevitably intertwined with questions of national identity and political autonomy. Within this general framework, Barcelona is a special case, precisely because of its global identity, many of its inhabitants identifying themselves primarily as Barcelonese, rather than either Catalan or Spanish (Delgado 2010: 67-70, 79-87). It is difficult to visit the city, even for the briefest period of time, without coming into contact with Catalan and without witnessing the fluid and sophisticated way in which locals mix both languages.

Yet, the city of $V C B$ is strictly Catalan free. Not once is the language heard or even seen in any road or shop signs. Vicky and Cristina are welcomed to Barcelona in English, their visit to the city's most popular sites is presented through a montage sequence unified by the English voice of the narrator, and they enter in contact with the local culture at an art exhibition where only English is heard by the spectator and, later, in English, through their conversation with Juan Antonio at the restaurant. Half way through the narrative, Spanish is brought in by María Elena, but Catalan is kept at bay. When the characters leave the city, they visit the nearby Parc de Collserola and the much more distant city of Oviedo as well as other parts of the region, Asturias. Yet no geographical or cultural distinction is made between all these different locations, leaving the unknowing spectator with the impression that they are all part of the same geopolitical reality. The two representatives of Catalan society are Juan Antonio and María Elena, neither of whom shows at any point any markers of any sort of Catalan identity. Juan Antonio is described as a local artist but this in practical terms means Spanish. Both Bardem and Cruz are Spanish and the narrative does not make any effort to explain why they live in Catalonia. Juan Antonio's father is presumably from Asturias which, in the absence of some further explanation, makes it more difficult to see him as 'a local artist'. The guitar music that Vicky loves and is played at several points in the film is either modern flamenco or classical Spanish music, even though Isaac Albéniz, the nineteenth century composer of two of the pieces that are heard, was Catalan. In spite of her openness to the other, Vicky does not appear to be aware at any point that such a thing as the Catalan language exists.

The Barcelona of $V C B$, therefore, lacks some vital ingredients. Yet, allowing for certain narrative incongruities, the way it is experienced by the international spectator may not be radically different from how a tourist visiting the city will understand it and represent it to others. The admiration for its singular architecture, the presence of traditional Spanish culture, and the blurring of borders with neighbouring identities, even the vague understanding of the existence of certain singularities, are all there. As with other global cities, there are many Barcelonas. The one we see in Allen's film is that of the foreign visitor who becomes enchanted with certain features and can recognize and celebrate its similarities with other capitals. This Barcelona is very close to the modelo Barcelona that city officials and business leaders are trying to promote. As we have seen, the gentrification of huge parts of the Ciutat 
Vella has managed to retain some of the neighbourhood's old flavour while, at the same time, bringing it closer to other gentrified areas in other cities around the world. $V C B$ records some of the consequences of this process of gentrification, calling attention to some of its contradictions: the Barcelona trademark, designed to sell the city to visitors and investors on the strength of its uniqueness, bases its appeal on the concealment of some of the traits that make the city unique, among them, its linguistic makeup and the heated debates around its identity. On the other hand, even the gentrified but bilingual and culturally more specific Ciutat Vella that many may have missed in Allen's movie only encompasses a relatively small part, however privileged and influential, of the city's identity. Some of the internal borders of Barcelona are operative in the narrative of $V C B$ but many others proliferate in the global city.

\section{BIUTIFUL AND THE PARADOXES OF THE TRANSNATIONAL CITY}

Questions of Catalan identity and Barcelonese singularity do not feature high in the agenda of the characters of Alejandro González Iñárritu's Biutiful. Early in the narrative we witness the persecution by the local police of a group of undocumented African immigrants who are selling illegal products downtown. Street sellers are a common feature of Barcelona and many other cities, always visible in city centres, always ready to vanish into side streets when warning comes that the police are near. They are so familiar that most people do not even notice their presence, yet they are an important part of contemporary cities, and a reliable manifestation of their economies. None of these people appear in $V C B$, just as the kind of characters that we see in Allen's film are absent from Biutiful. Rodrigo Prieto's camera, Stephen Mirrione's editing and Gustavo Santaolla's score create a fictional world which is as distant from the 'real' Ciutat Vella as that of VCB. Tourists are as incidental to this plot as undocumented immigrants are absent from Allen's movie. Beyond obvious generic and authorial divergences, a superficial comparison between this scene and the ones shot around the same area in $V C B$ illustrates how the global city encompasses a multitude of diverse narratives, and the capacity of cinema to turn this multiplicity into discourse. The very divergent visual and aural strategies employed by both film-makers make us aware of the polyphony of experience in the global city, the power and volatility of its internal borders and the multiplicity of ways in which, as De Certeau suggests in the lines quoted above, people accept, appropriate and react against the planning strategies of city officials, architects and urban designers.

The social privilege of the characters in $V C B$ and the often extreme marginality of those in Biutiful are directly related to the economic effects and shapes of globalization, including gentrification processes. As Smith reminds us, global cities are not only defined by gentrification, digital communication and production capital, but also by those practices that are generated by them but often multiply and branch off in unexpected directions (2002: 432). Saskia Sassen agrees that residential and commercial gentrification is one of the components of the more general process of globalization and digitation of cities, yet argues that from the displacements, segregations, and destructions of natural environments, and from the concentrations of built infrastructures that make digital transmission of wealth and power possible, new spaces of local power are born: 'The fact that the network is global does not mean that all that gets enacted in that network has to happen at the global level' 
(Sassen 2003: 26). Similarly, Jennifer Jordan contests those theories of globalization that portray a world in which the specificity of place and community are disappearing and being replaced by such global phenomena as edge cities, sweatshops and shopping malls. For her, local communities have the power to persist and re-emerge in new configurations. She sees the new cityscapes as places to 'investigate rather than presume the effects of globalization on communities and localities' (Jordan 2003: 32).

Manuel Castells defines the space of flows as a space organized for, as well as created by, the constant movement of people, goods and information, a space that exists to keep things moving around. But this new space coexists with the traditional space of places, where people live and engage in significant relations with one another. Castells sees a danger in the structural domination of the space of flows over the space of places, the former altering the meaning and dynamic of places, breaking down channels of communication in society, and taking power away from traditional locations. For him local networks and traditional forms of everyday communication and exchange are the victims of globalization in modern cities: 'It is this distinctive feature of being globally connected and locally disconnected, physically and socially, that makes mega-cities a new urban form' (Castells 2000: 436). Theorists like Sassen and Jordan, for their part, perceive a greater variety of positions of power. For them, gentrification and globalization produce certain urban designs but the dynamics created by these transformations do not always reproduce what was originally intended by those in control, and the outcomes may be surprising. These authors point to the micro-level of the global city, that which is inhabited by human beings rather than by powerful corporations and movements of capital in virtual space.

The majority of characters in Biutiful belong to the social groups that gentrification and other processes related to globalization have driven away from downtown areas and towards more distant neighbourhoods. Given Barcelona's geographical position, bordered by mountains, two rivers and the sea, the expansion of the city beyond its limits has mostly taken the form of incorporating nearby towns, once part of the industrial belt but distinct from it, and today, while remaining separate administrative entities, effectively part of the same conurbation. Biutiful hardly ever identifies the exact location of its action but a sizeable part of it was shot in Badalona and Santa Coloma de Gramenet (Figure 3). These towns are amongst the most thickly populated in Catalonia and have grown enormously with successive waves of immigration, initially from other parts of Spain and more recently from other countries in Africa, Latin America, Eastern Europe and Asia. In the 'Flip Notes' accompanying the DVD of the film (2010), Iñárritu celebrates the cultural and ethnic diversity that he found in Santa Coloma (2010). In spite of the film's generally harsh and depressing tone, some of this fascination with urban borderland culture also permeates Biutiful.

The film, set in the underworld of Barcelona's periphery, tells the story of Uxbal (Javier Bardem). An ambiguous and multifaceted character, Uxbal is, at once, the affectionate single father of two children, a middleman who does business with illegal immigrants, and a spiritual medium for the recently bereaved. His world, precarious, strange and dodgy, begins to crumble when he learns that he has only a few weeks left to live due to a terminal cancer. In the course of those few weeks, his world and that of the people around him his family and his immigrant friends - changes in dramatic and unexpected ways, all of them connected to the multifaceted transnational city. 
3. This term (in Catalan 'xarnego' or 'xarnec') is mostly used pejoratively to refer to Spanish-speakers who emigrate to Catalonia from other Spanish regions, or to children of mixed parentage: Catalan and nonCatalan (see Candel 1967; Puntí 2011)

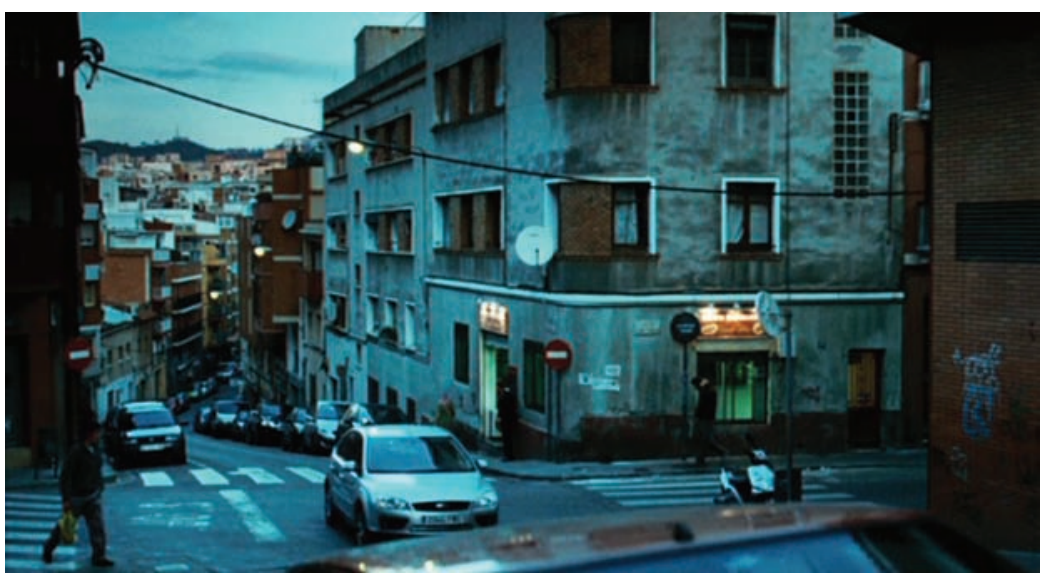

Figure 3: Sundown in Badalona.

It may be no coincidence that the ethnic makeup of the family of Uxbal (Javier Bardem) is never explained and remains puzzling: Mateo (Guillermo Estrella) and Ana (Hanaa Bouchaib) are children of the same mother and father, yet they appear to be racially different. Uxbal is Spanish, probably the son of immigrants to Catalonia from poorer Spanish regions, an inheritance which some Catalans describe through the ambiguous term 'charnego'. ${ }^{3}$ His estranged wife Marambra is Argentinian although it is curious that Maricel Álvarez, the actor who plays her part, has a different accent in the film from what appears to be her 'natural' Buenos Aires accent in the short interview included in the DVD extras. There is no apparent reason for her to adopt a northern Argentinian accent, except maybe that it sounds less marked, less 'Argentinian', than her own. Ana is played by Hanaa Bouchaib, a non-professional actor and the daughter of north African immigrants who the director met outside the school where he was shooting part of the film (Iñárritu 2011: 5-6). No time is spent in explaining why Uxbal (whose name is neither Spanish nor Catalan) does not have a Catalan accent when he speaks Spanish, whereas his brother Tito, played by Catalan actor Eduard Fernández, does. Not only is Iñárritu not interested in consistency in this respect but he intentionally breaks realism in order to foreground the hybrid makeup of his Barcelona and to familiarize us with the type of borderland experience to be found in great global cities. Although these national factors may go unnoticed for most non-Spanish viewers of a global film which is a Spanish Mexican co-production, they certainly contribute to the hybridity and transnational flavour of the final product.

Uxbal is both a product and embodiment of border identity and, through his powerful presence, transforms the city he inhabits into a borderland. Around him, most of the other important characters are immigrants from southern Spain, Africa, China and Latin America. The Catalan language is mostly absent; Spanish, on the other hand, is only one of the channels of communication, uttered in a great variety of fluent and less fluent ways. Iñárritu's Barcelona is as polyphonic and hybrid as Allen's is monolithic, but both films construct a city defined by its capacity to create border identities.

The Mexican director's optimistic take on everyday life in the global city in the DVD extras is not borne out by the information that we get in the
1.

2.

3.

4.

5.

6.

7.

8.

9.

10.

11.

12.

13.

14.

15.

16.

17.

18.

19.

20.

21.

22.

23.

24.

25.

26.

27.

28.

29.

30.

31.

32.

33.

34.

35.

36.

37.

38.

39.

40.

41.

42.

43.

44.

45.

46.

47.

48.

49.

50.

51.

52. 
media about social realities. While this article was being researched, local elections were held throughout Spain. The new mayor of Badalona, Xavier García Albiol, ran on a xenophobic electoral programme, linking crime with immigration and demanding harsher measures against immigrants. He is currently being investigated by a judge for inciting racial hatred in 2010 in a local campaign with the slogan 'We don't want Rumanians' (García 2011). The new extreme right-wing party, Plataforma per Catalunya, which received unexpected support from the voters in the Barcelona industrial belt, uses the derogatory term 'moros' for Arabs and blames North Africans for all the problems of society, campaigning for massive deportations. Given the conservative slant taken by the region, it is not unthinkable that in the near future, the Badalona of Biutiful will undertake gentrification projects similar to those of Ciutat Vella, directed to 'recuperate' the town for its middle classes and to drive the immigrants away.

Iñarritu's fourth feature is not a (an explicitly) political film yet these social and political realities are never far from its concerns. A memorable shot that was used in some of the film's trailers finds Uxbal walking along a flyover at sundown, his life shaken by tragedy (Figure 4). As he stops to look at some migrating birds framed against the darkening sky, an electoral van from a political party drives past and brings him out of his momentary reverie. The slogan displayed on the side of the van is Catalunya per als Catalans (Catalonia for the Catalans) followed by Treballem per una Catalunya pura (we are working for a pure Catalonia). This almost invisible incident reminds us of the context in which the characters live. Not one of them would be admitted into this 'Catalunya pura', and populist sloganeering like this automatically turns them into easy targets of widespread social rejection. Yet, against this hostile background they continue to struggle for survival and happiness, negotiating the constant threat posed by urban borders, those which give them their identity and allow them to continue the struggle.

Uxbal is the fulcrum around which a complicated financial and social underworld network revolves: he acts as middle man between the Chinese manufacturers of illegal goods in their sweatshops and the African street sellers, as well as looking for places for both groups to live. He finds work for the undocumented through contacts with construction bosses and through

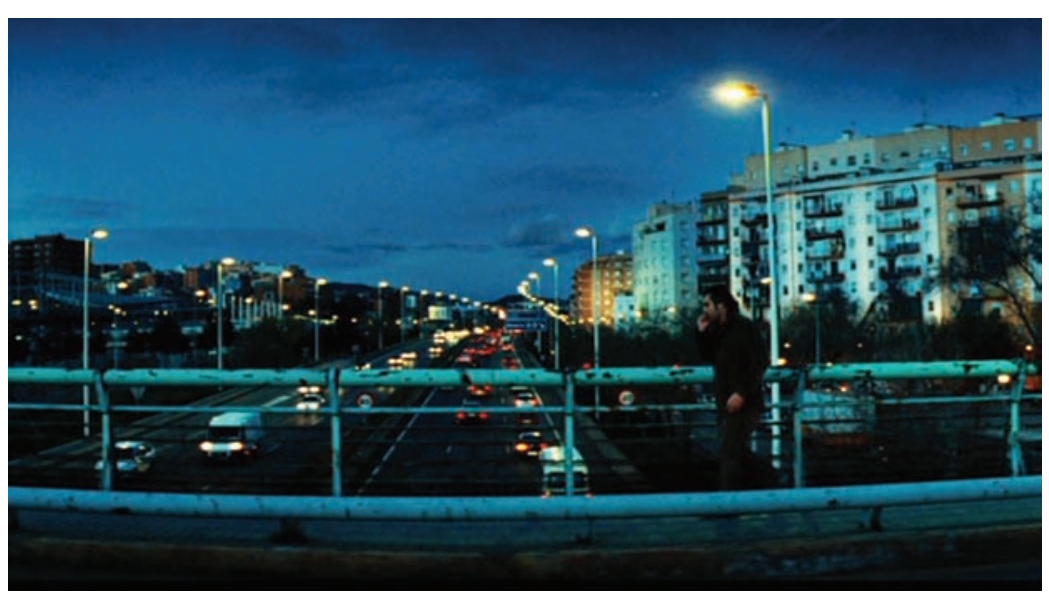

Figure 4: In transit: Uxbal crosses the flyover. 
his brother, apparently a low-profile businessman. He has contacts with the local police to make work possible for the Africans. He also moonlights as a medium with the recently dead, and does all this for a price. His generosity and empathy with the immigrants sits uneasily alongside the immorality of the way in which he exploits them, but that is the main source of fascination of this complex character. He dominates with his sometimes undecipherable personality over an intricate social network which palpitates with the life of the global city, yet is at the same time almost invisible to those who are not part of it. Uxbal's network illustrates and supports Sassen's and Jordan's insights on the consequences of globalization in cities. Driven to specific urban spaces both by gentrification and their status as undocumented citizens, the characters in Biutiful draw their own blueprint of Barcelona. Armed with their extreme form of mobility, they traverse the city every day. De Certeau argues that 'the art of walking' defines to a great extent the individual citizen's appropriation of the city:

In spite of the inequality of its citizens' positions and profits there is only a pullulation of passers-by, a network of residences temporarily appropriated by pedestrian traffic, a shuffling among pretenses of the proper, a universe of rented spaces haunted by a nowhere of dreamed-of places.

(1984: 104)

Uxbal perfectly fits this description: constantly on the move, he controls an alternative universe of rented spaces, which he constantly redraws with his progress. He is a consummate practitioner of the urban network precisely because of his ability to negotiate borders and to cross them even as he contributes to their thickening.

Globalization produces a specific type of ever-expanding urban design, but its financial transactions, its spaces of flows, and its powerful corporations do not tell the whole story and they are not enough to explain its impact on people. Gentrification policies aspire to redesign cities for the benefit of the middle classes, the tourist industry, and the big corporations, but individuals learn to recreate their own links with the city. The urban world Biutiful constructs illustrates the energy that Jordan finds in local communities and their ability to re-emerge in the face of the challenges posed by global phenomena. Even when Iñáritu's vision is tragic and the general tone of the film is somber in its display of an urban community always on the brink of displacement, despair, and death, Biutiful nevertheless revels in its vibrancy, resilience and humanity. This underground universe also generates its own spaces of power, as Sassen asserts, but here the dynamics of these power spaces differ from global schemata and create more volatile, ambiguous and unpredictable relationships.

While Uxbal dominates the film, the only comparable player in Biutiful is the city itself, both an extension of the protagonist's personality and an infinitely complex space where many similar networks seem to be at work. While Iñárritu's Barcelona is virtually devoid of recognizable landmarks, situating itself on the opposite pole from $V C B$ in this respect, there is an important exception: the power station of Sant Adrià del Besòs. The massive structure on the seafront punctuates the narrative visually and plays an important part in the plot, since the underground room where the Chinese workers die from suffocation is located next to it (Figure 5). As visible to the visitor or inhabitant of the city as the Sagrada Familia or the Agbar Tower, this industrial

1. 2. 3. 4. 5. 6. 7. 8. 9. 10. 11. 12. 
building dominates the Barcelona skyline, for some a welcome reminder of the city's industrial past and for others simply an eyesore. The station was built in the 1970s on the mouth of the Besòs River, which constitutes the northern boundary of the original city and separates it from the industrial belt. The area includes the towns of Sant Adrià del Besòs, Badalona and Santa Coloma de Gramanet, populated predominantly by first-generation and second-generation Spanish immigrants and, more recently, by newcomers from other countries. The building marks the historical expansion of the city North of its original limits, and represents a visual chronicle of the changes in its recent history. Some of those first-generation immigrants found work precisely at this facility when they first went to Catalonia. Many of them had spent much of their working lives in it when operations came to a halt and its industrial activity was discontinued (Bonmatí 2011). The building has recently become a huge metal skeleton, its walls and windows rapidly deteriorating to the eye of the close observer. However, according to the official page of the company that managed it, the three chimneys will remain in place as a result of the decision of the town of Sant Adrià after having carried out a survey among its citizens (Endesaeduca web page). They will become a reminder of the working-class community of the area.

Given the specific location of the building, it seems unlikely that Biutiful has reproduced the topography of its surroundings faithfully. The film-makers, however, may have made the connection with the nearby Polígono Sur of Badalona, a huge industrial estate, occupied for the most part nowadays by Chinese-owned wholesale businesses that provide merchandise for clothes outlets, market sellers and other players in today's alternative economy. In the same way as the Gaudí monuments represent the cultural interests of the type of characters that populate $V C B$, the power station reflects the past and present history of immigration by focusing on the most visible landmark of an area famous for the conflicts and tensions between yarious immigrant working-class and displaced social groups (Delgado 2010: 142-56). For those who are familiar with the power station, its presence in Biutiful will evoke the more specific meanings of the area, but for those who are not it still represents the

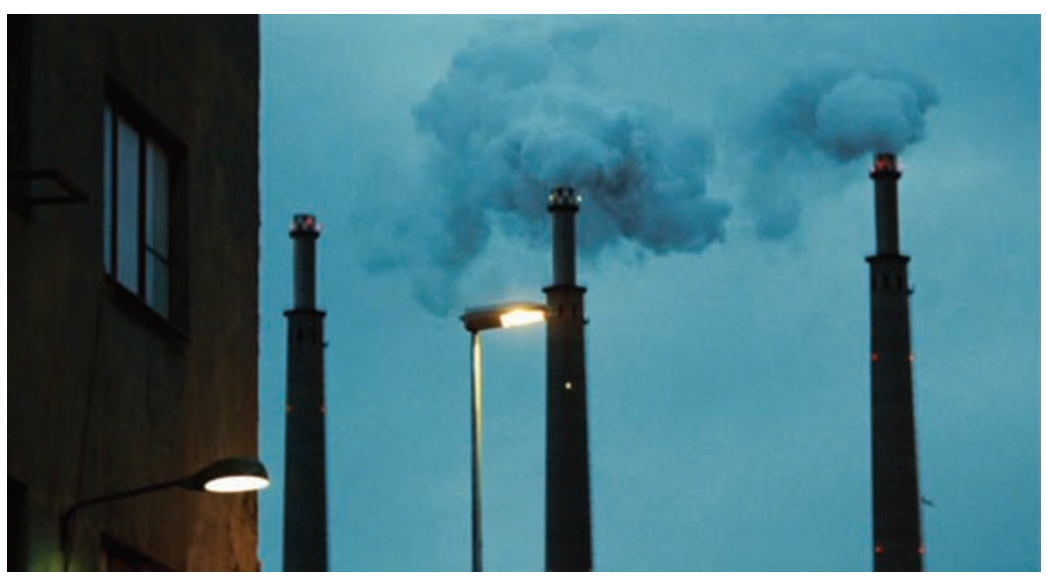

Figure 5: Historical landmark or eyesore?: The imposing towers of Sant Adrià's power station. 
urban world of immigrants, jobless and displaced citizens who eke out a living in the backyard of the powerful global companies and on the edge of the official discourses.

Beyond these various layers of obvious meanings, the fact that the facility has come into disuse since Biutiful was released alters the connotations of its presence in the film in a curious way. For Delgado, modern global cities present themselves as monuments, strengthening the signs of collective identity that will help reduce the tendency towards fragmentation and heterogeneity in big metropolis. Barcelona, like other cities, has consistently carried out what he calls a politics of place and a politics of urban memory, imposing its own symbolic productions over those of its individual citizens. One way in which this has been articulated in the Catalan capital has been through the emptying out of the original meanings of old industrial buildings, evocative of the industrial and bourgeois Barcelona of the early twentieth century, and their conversion into signifiers of the new post-industrial, sanitized city. This institutionalization of memory is embodied in the case of Barcelona in the authorities' obsession with the preservation of chimneys, integrating these industrial ruins into new architectural landscapes. These official projects apparently celebrate the exciting and convulsive period of the first decades of the last century. At this time the powerful forces of capitalistic modernization constantly clashed with the equally strong anarchistic and revolutionary movements that once inhabited it. In those years Barcelona was nicknamed 'the Rose of Fire', the vibrant metropolis where history was being made from day to day, and possibly a historical model for the contemporary city to live up to. Yet what the chimneys-turned-monuments do is, according to Delgado, quite the opposite: they tell us that the past is gone and that the great factories and workshops of which they were part once have now become sites of consumption and advertisements of the capitalistic commodity that the city has now become (Delgado 2010: 95-102). Under this light, the presence of the power station of Sant Adrià in Biutiful not only evokes the global city as populated by the displaced and the undocumented, but it also endorses the 'modelo Barcelona' and becomes part of the official discourse. It integrates the old power station within the object of high culture that the film is, one more commodity that sells the Barcelona trademark within the festival circuit and art-cinemagoers elite where Biutiful most comfortably fits, regardless of the specific meanings of the story it tells.

While Biutiful is perhaps not the most obvious text for any self-respecting tourist board to use as advertisement for the Barcelona trademark, the film itself ultimately feeds into the discourse of the modern global city and contributes to the visibility of Barcelona as an interesting and exciting destination for tourists, foreign investment and international cultural events. The apparent contradiction between the film's endorsement of the 'product Barcelona' and its moving dissection of the forms of injustice and oppression generated by contemporary global phenomena ultimately constitutes an example of the multifaceted and paradoxical nature of the modern city as discourse.

\section{CONCLUSION}

$V C B$ and Biutiful belong to the same discursive space in which fiction films operate as part of a cultural strategy that complements urban and political initiatives. They contribute to the imaginary construction of Barcelona as a fascinating global city. At the same time, they can be seen as a diptych of

1. 2. 3. 4. 5. 6. 7. 8. 9. 10. 11. 12. 13. 14. 15. 16. 17. 18. 19. 20. 21. 22. 23. 24. 25. 26. 27. 28. 29. 30. 31. 32. 33. 34. 35. 36. 37. 38. 39. 40. 41. 42. 43. 44. 45. 46. 47. 48. 49. 50. 51. 52. 
1.

a transnational Barcelona. In this composite picture, movements of different kinds link the two narratives, reminding us both of the fluid nature of the network and of the daily reconstruction and redrawing of the human geography of the contemporary city by its citizens. Both films create an imagined Barcelona but, in their drastically divergent ways, they both reveal important aspects and dimensions of the 'real' city. Like the multitude of 'invisible cities' through which Marco Polo gives Kublai Kahn different versions of his native Venice in Italo Calvino's classic tale, the spectator learns as much about the city from one film as from the other. Even better, we experience the two cities at the same time and take in both the resilience and versatility of the borders that are permanently being redrawn both by urban policy and the daily activity of its citizens. While the characters of $V C B$ and Biutiful never meet, they all appear fascinated by the energy irradiating from the invisible barriers erected between them, and fascinate us, in their turn, with the stubbornness of their negotiations of the borderlands from which they derive their identities and inform their most intimate encounters.

\section{ACKNOWLEDGMENTS}

Research towards this article was carried out with the help of research project no. FFI2010-15312 of the Spanish Ministry of Science and Innovation and the DGA reference no. H12. We would also like to thank Josep Lluís Fecé, Melissa Moyer and the editors of Transnational Cinema for their help with earlier versions of this manuscript.

\section{REFERENCES}

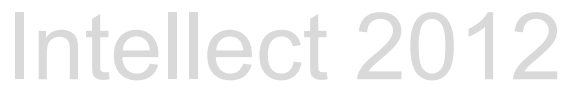

Allen, W. (2008), Vicky Cristina Barcelona, Mediapro Gravier Productions.

Bonmatí, D. (2011), ‘La última noche en la central térmica de Sant Adrià', Finanzas.com, 19 March, http://www.finanzas.com/noticias/ empresas/2011-03-19/449493_ultima-noche-central-termica-sant.html. Accessed 21 October 2011.

Caellas, M. (2011), Carcelona, Barcelona: Melusina.

Calvino, I. ([1972] 1993), La città invisibili, Milan: Oscar Mondadori.

Candel, F. (1967), Els altres catalans, Barcelona: Edicions 62.

Casas, Q. (2011), 'Biutiful, realismo impostado', El Periódico, 3 December 2010, http://www.elperiodico.com/es/noticias/ocio-y-cultura/20101203/biutifulrealismo-impostado/607790.shtml. Accessed 21 November 2011.

Castells, M. (2000), The Rise of the Network Society, Oxford: Blackwell. (2004), The Power of Identity, Malden, Oxford, Victoria: Blackwell.

De Certeau, M. (1984), The Practice of Everyday Life (trans. S. Randall), Berkeley, Los Angeles, and London: University of California Press.

Delgado, M. (2010), La ciudad mentirosa: Fraude y miseria del modelo Barcelona, Madrid: Catarata.

Duurovičová, N. (2003). 'Los Toquis, or Urban Babel', in L. Krause and P. Petro (eds), Global Cities: Cinema, Architecture, and Urbanism in a Digital Age, New Brunswick, New Jersey, and London: Rutgers University Press, pp. $71-86$.

Endesaeduca (2011), 'Cierre de la central térmica de Sant Adrià', endesaeduca, http://www.endesaeduca.com/opencms/opencms/Endesa_educa_ Gallego/conocenos/actualidad/cierre-Central-Sant-Adria. Accessed 26 October 2011. 
García, J. (2011), 'Ahídonde triunfa el miedo', El País, 12 June, http://www.elpais. com/articulo/espana/Ahi/triunfa/miedo/elpepiesp/20110612elpepinac_7/ Tes Accessed 12 June 2011.

Iñárritu, A. G. (2010), Biutiful, Focus Features.

- (2011), "“On Biutiful" "Biutiful production notes"', Optimum Releasing.

Jordan, J. (2003), 'Collective memory and locality in global cities', in L. Krause and P. Petro (eds), Global Cities: Cinema, Architecture, and Urbanism in a Digital Age, New Brunswick, New Jersey, and London: Rutgers University Press, pp. 31-48.

Marfany, J. L. (1995), La cultura del catalanisme, Barcelona: Empúries.

Montaner, J. M. (1986), 'Barcelona i la propaganda', Repensar Barcelona, Barcelona: Edicions de la Universitat Politècnica de Barcelona.

Puntí, J. (2011), Els castellans, Barcelona: L'Avenç.

Sánchez, S. (2011), 'Vicky Cristina Barcelona', Fotogramas, September 2008, http://www.fotogramas.es/Peliculas/Vicky-Cristina-Barcelona/Critica. Accessed 21 November 2001.

Sassen, S. (2003), 'Reading the city in a global digital age: Between topographic representation and spatialized power projects', in L. Krause and P. Petro (eds), Global Cities: Cinema, Architecture, and Urbanism in a Digital Age, New Brunswick, New Jersey, and London: Rutgers University Press, pp. 15-30.

Schaffer, R. and Smith, N. (1986), 'The gentrification of Harlem?', Annals of the Association of American Geographers, 76: 3, September, pp. 347-65.

Seabrook, J. (2008), Ciutats, Barcelona: Edicions Intermón Oxfam.

Shaw, D. (2007), 'Blow: How a film created a hero from a top-level drug trafficker and blamed the "Colombians" for his downfall', Quarterly Review of Film and Video, 24, pp. 31-40.

Smith, N. (1982), 'Gentrification and uneven development', Economic Geography, 58:2, April, pp. 139-55.

(2002), 'New globalism, new urbanism: Gentrification as global urban strategy', Antipode, 34, pp. 427-50.

\section{SUGGESTED CITATION}

Deleyto, C. and López, G. (2012), 'Catalan beauty and the transnational beast: Barcelona on the screen', Transnational Cinemas 3: 2, pp. 157-175, doi: 10.1386/ trac.3.2.157_1

\section{CONTRIBUTOR DETAILS}

Celestino Deleyto is Professor of English Literature and Film at the University of Zaragoza. He belongs to the research group 'Cinema, Culture and Society' and is currently working on the Project 'Humpty Dumpty on the wall: Transnationalism and the border in contemporary cinema'. He is the author of The Secret Life of Romantic Comedy (Manchester University Press, 2009) and co-author, with María del Mar Azcona, of Alejandro González Iñárritu (The University of Illinois Press, 2010).

Contact: Departamento de Filología Inglesa y Alemana, Facultad de Filosofía y Letras, Universidad de Zaragoza. Pedro Cerbuna 12, 50009 Zaragoza, Spain. E-mail: cdeleyto@unizar.es 
1. Gemma López teaches English Literature at the University of Barcelona. 2. She is currently working on the Project 'Humpty Dumpty on the wall: 3. Transnationalism and the border in contemporary cinema'. She is the author 4. of Seductions in Narrative: Subjectivity and Desire in the Works of Angela Carter 5. and Jeanette Winterson (New York: Cambria Press, 2007).

Contact: Departament de Filologia Anglesa I Alemanya, Facultat de Filologia, Universitat de Barcelona. Gran Via de les Corts Catalanes, 585, Barcelona 08007, Spain.

10. E-mail: gemma_lopez@ub.edu

11.

12.

13.

14.

15.

16.

17.

18.

19.

20.

21.

22.

23.

24.

25.

26.

27.

28.

29.

30.

31.

32.

33.

34.

35.

36.

37.

38.

39.

40.

41.

42.

43.

44.

45.

46.

47.

48.

49.

50.

51.

52.

Celestino Deleyto and Gemma López has asserted their right under the Copyright, Designs and Patents Act, 1988, to be identified as the author of this work in the format that was submitted to Intellect Ltd.

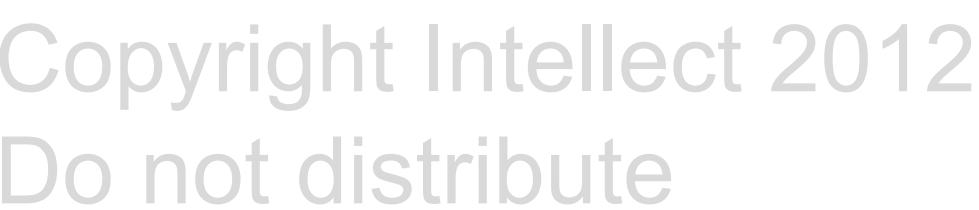

